\title{
Chemical composition and droplet size distribution of cloud at the summit of Mount Tai, China
}

\author{
Jiarong Li ${ }^{1}$, Xinfeng Wang ${ }^{1}$, Jianmin Chen ${ }^{1,2,3}$, Chao Zhu ${ }^{1}$, Weijun $\mathrm{Li}^{1}$, Chengbao $\mathrm{Li}^{2}$, Lu Liu ${ }^{1}$, Caihong Xu ${ }^{1}$, \\ Liang Wen ${ }^{1}$, Likun Xue ${ }^{1}$, Wenxing Wang ${ }^{1}$, Aijun Ding ${ }^{3}$, and Hartmut Herrmann ${ }^{2,4}$ \\ ${ }^{1}$ Environment Research Institute, School of Environmental Science and Engineering, Shandong University, \\ Ji'nan, 250100, China \\ ${ }^{2}$ Shanghai Key Laboratory of Atmospheric Particle Pollution and Prevention, Department of Environmental Science \\ and Engineering, Institute of Atmospheric Sciences, Fudan University, Shanghai, 200433, China \\ ${ }^{3}$ Institute for Climate and Global Change Research, School of Atmospheric Sciences, Nanjing University, \\ Nanjing, 210023, Jiangsu, China \\ ${ }^{4}$ Leibniz Institute for Tropospheric Research (TROPOS), Atmospheric Chemistry Department (ACD), \\ Permoserstr. 15, 04318, Leipzig, Germany
}

Correspondence to: Jianmin Chen (jmchen@fudan.edu.cn, jmchen@sdu.edu.cn) and Hartmut Herrmann (herrmann@ tropos.de)

Received: 8 January 2017 - Discussion started: 16 February 2017

Revised: 11 June 2017 - Accepted: 25 July 2017 - Published: 23 August 2017

\begin{abstract}
The chemical composition of 39 cloud samples and droplet size distributions in 24 cloud events were investigated at the summit of Mt. Tai from July to October 2014. Inorganic ions, organic acids, metals, $\mathrm{HCHO}, \mathrm{H}_{2} \mathrm{O}_{2}$, sulfur(IV), organic carbon, and elemental carbon as well as $\mathrm{pH}$ and electrical conductivity were analyzed. The acidity of the cloud water significantly decreased from a reported value of pH 3.86 during 2007-2008 (Guo et al., 2012) to pH 5.87 in the present study. The concentrations of nitrate and ammonium were both increased since 2007-2008, but the overcompensation of ammonium led to an increase in the mean $\mathrm{pH}$ value. The microphysical properties showed that cloud droplets were smaller than $26.0 \mu \mathrm{m}$ and most were in the range of 6.0-9.0 $\mu \mathrm{m}$ at Mt. Tai. The maximum droplet number concentration $\left(N_{\mathrm{d}}\right)$ was associated with a droplet size of $7.0 \mu \mathrm{m}$. High liquid water content (LWC) values could facilitate the formation of larger cloud droplets and broadened the droplet size distribution. Cloud droplets exhibited a strong interaction with atmospheric aerosols. Higher $\mathrm{PM}_{2.5}$ levels resulted in higher concentrations of water-soluble ions and smaller sizes with increased numbers of cloud droplets. The lower $\mathrm{pH}$ values were likely to occur at higher $\mathrm{PM}_{2.5}$ concentrations. Clouds were an important sink for soluble materials in the atmosphere. The dilution effect of cloud water
\end{abstract}

should be considered when estimating concentrations of soluble components in the cloud phase.

\section{Introduction}

Cloud droplets are formed by the condensation of water vapor on anthropogenic and natural aerosols that serve as cloud condensation nuclei (CCN). Clouds significantly affect the earth's radiation budget and they are also responsible for the changes in regional and global climate (Miles et al., 2000). Cloud events can transport pollutants, promote acid deposition, change the meteorological conditions, modify local environmental features and affect the fate of several atmospheric species via chemical and physical processes (Moore et al., 2004).

The chemical properties of clouds are initially determined by CCN (Sun et al., 2010). However, they can be altered by absorbing chemical components of soluble gases and further multiphase chemical reactions taking place in the cloud phase (Ravishankara, 1997). Non-precipitating clouds play a more crucial role in ion deposition and aggregation than precipitating clouds do (Aleksic et al., 2009). The concentrations of soluble compounds and dissolved acids have gener- 
ally been reported to be much higher in cloud liquid water compared with precipitation (Błaś et al., 2008; Zapletal et al., 2007; Zimmermann et al., 2003). For example, Sun et al., (2010) found that the concentrations of ammonium, sulfate and nitrate in cloud water were at least 5.17 times higher than those in rainwater.

Cloud plays a significant role in scavenging aerosols via drop deposition (directly or by coalescence into precipitation) and in creating new particles and trace gases (Herckes et al., 2002). These processes could influence the distribution and the concentration of pollutants both in the cloud phase and in the aerosol phase, and also influence the microphysical properties of the clouds (Collett Jr. et al., 2002; Lee et al., 2012; Ogawa et al., 2000). For example, for a given supersaturated condition, an increase in the concentration of $\mathrm{CCN}$ will lead to the formation of small droplets (Borys et al., 2000; Gultepe and Milbrandt, 2007). In addition, the cloud droplet size distribution (CDSD) is prominently determined by the chemical and physical properties of CCN (Portin et al., 2014; Zipori et al., 2015). Numerous studies have examined the chemical compositions of orographic clouds (Kim et al., 2006; Marinoni et al., 2004; Watanabe et al., 2010), many of which have focused on the size-dependent chemical properties of the clouds (Moore et al., 2004; Schell et al., 1997). However, few studies provide detailed descriptions of the interactions between aerosols and the chemical and microphysical properties of clouds.

In this study, cloud samples were collected at the summit of Mt. Tai. It is interesting that the acidity of the cloud water was significantly lower than that reported during 2007-2008 (Guo et al., 2012; Wang et al., 2011). The causes behind this change were investigated by examining the chemical compositions of cloud samples at Mt. Tai. We then investigated the microphysical properties of cloud droplets, including CDSD, LWC, effective diameter (ED) and droplet number concentration $\left(N_{\mathrm{d}}\right)$. Lastly, we explored the interactions between cloud droplets and aerosols in the atmosphere.

\section{Methods}

\subsection{Site description and sampling}

Mt. Tai $\left(117^{\circ} 13^{\prime} \mathrm{E}, 36^{\circ} 18^{\prime} \mathrm{N} ; 1545 \mathrm{~m}\right.$ a.s.l.) is a natural and cultural heritage site in China and it is one of the world's geoparks. Because the summit of Mt. Tai lacks emissions of anthropogenic pollution, the pollutants investigated from there could accurately represent the characteristics of the regional pollutants in the North China Plain. The highfrequency of local cloud events, especially in summer, makes Mt. Tai a favorable site for collecting cloud samples and monitoring cloud events. Previous research has indicated that the clouds at the summit of Mt. Tai are acidic (Wang et al., 2008).
From 24 July to 31 October 2014, a total of 85 cloud samples associated with 24 cloud events were collected using a single-stage Caltech active strand cloud-water collector (CASCC), as described by Demoz et al. (1996), and 39 cloud samples were analyzed. The cloud droplets were drawn into the collector by a fan with a flow rate of $24.5 \mathrm{~m}^{3} \mathrm{~min}^{-1}$ and impacted on six Teflon nets that each contained 102 strands of $508 \mu \mathrm{m}$ in diameter. The samples were then guided along a groove at the bottom of the collector and finally collected into a $500 \mathrm{~mL}$ high-density polyethylene cylinder. The theoretical $50 \%$ collection efficiency cut-off size of the cloud droplets is at $3.5 \mu \mathrm{m}$. In this study, sampling-time resolution was adjusted during sampling sessions in order to ensure that each sample contained an adequate amount of cloud water for the analysis (at least $150 \mathrm{~mL}$ ). The volumes of the samples, the start and end times of the collection sessions and the numbers of collected samples were accurately recorded for each cloud event.

It should be noted that the collector was immediately shut down during precipitation to eliminate the interruptions caused by rain water. Before each sampling session, the collector was rinsed with high-purity deionized water $(\geq 18.2 \mathrm{M} \Omega$ ), dried naturally and sealed. Blanks were prepared using high-purity deionized water, and then they were treated and analyzed using the same method as collected samples.

\subsection{In situ and laboratory analysis}

The $\mathrm{pH}$, electrical conductivity and the concentrations of sulfur(IV), formaldehyde and hydrogen peroxide were measured immediately after sampling. Approximately $10 \mathrm{~mL}$ of each cloud sample was used to measure the $\mathrm{pH}$ and electrical conductivity by using a portable $\mathrm{pH}$ meter (model 6350M, JENCO) that was regularly calibrated using standard solutions at $\mathrm{pH}=4$ and $\mathrm{pH}=7$. Approximately $20 \mathrm{~mL}$ of each cloud sample was filtered using a cellulose acetate filter with pore sizes of $0.45 \mu \mathrm{m}$ to remove any suspended particulate matter and then the concentrations of sulfur(IV), formaldehyde and hydrogen peroxide were analyzed in situ to avoid any changes in their concentrations. The measurement methods were described in detail by Collett and colleagues (Collett Jr. et al., 1998). For each sample, a $10 \mathrm{~mL}$ aliquot was prepared for trace metal analysis by adding $1 \%(v / v)$ nitric acid and then preserved in a brown glass bottle at $4{ }^{\circ} \mathrm{C}$. Another $10 \mathrm{~mL}$ aliquot was prepared to analyze organic acids by adding $0.5 \%(v / v)$ chloroform (to prevent the reproduction of microorganisms) and then storing the solution in a glass bottle at $4{ }^{\circ} \mathrm{C}$. The residuals were refrigerated at $-20^{\circ} \mathrm{C}$ for further analysis.

The concentrations of eight inorganic ions $\left(\mathrm{Cl}^{-}, \mathrm{NO}_{3}^{-}\right.$, $\mathrm{SO}_{4}^{2-}, \mathrm{NH}_{4}^{+}, \mathrm{Na}^{+}, \mathrm{K}^{+}, \mathrm{Ca}^{2+}$ and $\mathrm{Mg}^{2+}$ ) in each sample were measured using an ion chromatograph (Dionex, ICS-90) and the concentrations of four organic acids (acetate, formate, oxalate and lactate) were measured using ion- 
Table 1. Summary of the chemical compositions for cloud samples collected at Mt. Tai during July to October 2014.

\begin{tabular}{|c|c|c|c|c|c|c|}
\hline Species & Units & No. samples & Min & $\operatorname{Max}$ & $V_{W M}{ }^{b}$ & Percentage \\
\hline $\mathrm{pH}$ & - & 39 & 3.80 & 6.93 & 5.87 & - \\
\hline Electrical conductivity & $\mu \mathrm{S} \mathrm{cm}^{-1}$ & 39 & 44.9 & 813.5 & 169.0 & - \\
\hline $\mathrm{Na}^{+}$ & $\mathrm{mg} \mathrm{L}^{-1}$ & 39 & $\mathrm{BDL}^{\mathrm{a}}$ & 2.9 & 0.9 & 0.56 \\
\hline $\mathrm{NH}_{4}^{+}$ & $\mathrm{mg} \mathrm{L}^{-1}$ & 39 & 5.2 & 143.3 & 34.2 & 21.41 \\
\hline $\mathrm{K}^{+}$ & $\mathrm{mg} \mathrm{L}^{-1}$ & 39 & $\mathrm{BDL}^{\mathrm{a}}$ & 6.5 & 1.3 & 0.81 \\
\hline $\mathrm{Mg}^{2+}$ & $\mathrm{mg} \mathrm{L}^{-1}$ & 39 & 0.2 & 3.0 & 0.7 & 0.44 \\
\hline $\mathrm{Ca}^{2+}$ & $\mathrm{mgL}^{-1}$ & 39 & $\mathrm{BDL}^{\mathrm{a}}$ & 39.2 & 5.9 & 3.69 \\
\hline $\mathrm{Cl}^{-}$ & $\mathrm{mg} \mathrm{L}^{-1}$ & 39 & 0.6 & 11.7 & 2.9 & 1.82 \\
\hline $\mathrm{NO}_{3}^{-}$ & $\mathrm{mg} \mathrm{L}^{-1}$ & 39 & 2.7 & 538.5 & 56.4 & 35.31 \\
\hline $\mathrm{SO}_{4}^{2-}$ & $\mathrm{mg} \mathrm{L}^{-1}$ & 39 & 10.5 & 253.0 & 44.2 & 27.67 \\
\hline nss-SO & $\mathrm{mg} \mathrm{L}^{-1}$ & 39 & 10.5 & 251.6 & 43.7 & 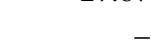 \\
\hline Lactate & $\mathrm{mg} \mathrm{L}^{-1}$ & 13 & $\mathrm{BDL}^{\mathrm{a}}$ & 7.8 & 3.0 & 1.88 \\
\hline Acetate & $\mathrm{mg} \mathrm{L}^{-1}$ & 15 & $\mathrm{BDL}^{\mathrm{a}}$ & 14.9 & 4.1 & 2.57 \\
\hline Formate & $\mathrm{mg} \mathrm{L}^{-1}$ & 17 & 0.4 & 14.4 & 2.8 & 1.75 \\
\hline Oxalate & $\mathrm{mg} \mathrm{L}^{-1}$ & 17 & 0.6 & 3.6 & 1.3 & 0.81 \\
\hline $\mathrm{Mn}$ & $\mathrm{mg} \mathrm{L}^{-1}$ & 39 & 0.01 & 0.28 & 0.04 & 0.03 \\
\hline $\mathrm{Fe}$ & $\mathrm{mg} \mathrm{L}^{-1}$ & 39 & 0.06 & 3.02 & 0.40 & 0.25 \\
\hline $\mathrm{HCHO}$ & $\mathrm{mg} \mathrm{L}^{-1}$ & 39 & $\mathrm{BDL}^{\mathrm{a}}$ & 5.9 & 0.4 & 0.25 \\
\hline $\mathrm{H}_{2} \mathrm{O}_{2}$ & $\mathrm{mg} \mathrm{L}^{-1}$ & 39 & $\mathrm{BDL}^{\mathrm{a}}$ & 3.3 & 0.8 & 0.50 \\
\hline S(IV) & $\mathrm{mg} \mathrm{L}^{-1}$ & 39 & $\mathrm{BDL}^{\mathrm{a}}$ & 1.1 & 0.4 & 0.25 \\
\hline $\mathrm{OC}^{\mathrm{c}}$ & $\mathrm{mg} \mathrm{L}^{-1}$ & 17 & $\mathrm{BDL}^{\mathrm{a}}$ & 211.8 & 37.4 & - \\
\hline$E C^{d}$ & $\mathrm{mg} \mathrm{L}^{-1}$ & 17 & $\mathrm{BDL}^{\mathrm{a}}$ & 8.5 & 0.3 & - \\
\hline Average $\mathrm{PM}_{2.5}$ level & $\mu \mathrm{g} \mathrm{m}^{-3}$ & 39 & 0.7 & 81.6 & 15.9 & - \\
\hline
\end{tabular}

${ }^{\mathrm{a}}$ BDL means below detection limit, ${ }^{\mathrm{b}}$ volume weighted mean concentration, ${ }^{\mathrm{c}} \mathrm{OC}$ means organic carbon, ${ }^{\mathrm{d}} \mathrm{EC}$ means elemental carbon.

chromatography (Dionex, IC-2500) (Guo et al., 2012; Yang et al., 2012). Trace metals such as Fe and Mn were analyzed using inductively coupled plasma mass spectrometry (ICPMS; Agilent 7500a). The concentrations of organic carbon (OC) and elemental carbon (EC) in cloud water were determined using a thermal-optical transmittance (TOT) carbon analyzer (Sunset Laboratory, Tigard, OR, USA). For each cloud sample, a small amount was dropped onto the surface of a small standard-size punch $\left(\sim 1.5 \mathrm{~cm}^{2}\right)$ from a precombusted quartz filter and analyzed based on the NIOSH protocol 870 TOT program (Khan et al., 2009; Xu et al., 2017).

\subsection{Monitoring of microphysical parameters}

A fog monitor (model FM-120, Droplet Measurement Technologies Inc., USA) was used in situ to monitor the LWC, the median volume diameter (MVD), the effective diameter (ED) and $N_{\mathrm{d}}$ of the cloud droplets with a time resolution of $1 \mathrm{~s}$ (for specifications, see Droplet Measurement Technologies, 2012). During 24 July to 23 August 2014, 24 cloud events were monitored. The measuring range of cloud droplet diameters was from 2 to $50 \mu \mathrm{m}$, divided into 20 bins. The sample velocity is $15 \mathrm{~m} \mathrm{~s}^{-1}$ and the sampling flow is $1 \mathrm{~m}^{3} \mathrm{~min}^{-1}$. Cloud droplets can not be efficiently collected at low LWC and $N_{\mathrm{d}}$ values. Based on our experience, the sampling limitations associated with LWC and $N_{\mathrm{d}}$ were $0.01 \mathrm{~g} \mathrm{~m}^{-3}$ and $60 \mathrm{~cm}^{-3}$, respectively.

\subsection{Measurements of ambient air pollutants and meteorological parameters}

The concentrations of inorganic water-soluble ions, the levels of $\mathrm{PM}_{2.5}$ and the meteorological parameters were monitored in real time during the observation periods. The $\mathrm{SO}_{4}^{2-}, \mathrm{NO}_{3}^{-}$ and $\mathrm{NH}_{4}^{+}$in $\mathrm{PM}_{2.5}$ were measured using two online ion chromatographs coupled with a wet rotating denuder and a steamjet aerosol collector (Marga ADI 2080, Applikon-ECN). A beta attenuation and optical analyzer (model 5030 SHARP monitor, Thermo Scientific) was used to monitor the levels of $\mathrm{PM}_{2.5}$. Meteorological parameters including the ambient temperature, relative humidity, wind speed and wind direction were measured using an automatic meteorological station. 


\section{Results and discussion}

\subsection{Chemical properties of cloud water}

\subsubsection{Acidity}

The $\mathrm{pH}$ values, electrical conductivity and chemical compositions (inorganic ions, organic acids, metals, $\mathrm{HCHO}, \mathrm{H}_{2} \mathrm{O}_{2}$, sulfur(IV), OC and EC) of the cloud droplets are summarized in Table 1 . The $\mathrm{pH}$ of the cloud water varied widely from 3.80 to 6.93 . The volume-weighted mean (VWM) $\mathrm{pH}$ was 5.87 , which is slightly higher than the background $\mathrm{pH}$ of 5.6 yielded by $\mathrm{CO}_{2}$ in the atmosphere. The analyzed 39 cloud samples were divided into two groups. One contained 17 summer samples (i.e., those that were collected from July to August) and the other group contained 22 autumn samples (i.e., those that were collected from September to October). About $52 \%$ of the summer samples were under $\mathrm{pH} 5.6$ and $12 \%$ were under $\mathrm{pH} 4.5$. The corresponding percentages for the autumn samples were 14 and $9 \%$, respectively. This means that some of the cloud samples at Mt. Tai were acidic, especially in the summer. If comparing with other orographic stations less affected by anthropogenic pollution, the VWM $\mathrm{pH}$ of clouds at Mt. Tai was higher, as shown in Table 2. Moreover, the VWM pH at Mt. Tai significantly increased from a reported value of 3.86 during 2007-2008 (Guo et al., 2012) to 5.87 in the present study. The detailed reasons for the big decrease in cloud-water acidity are discussed in Sect. 3.1.2.

\subsubsection{Chemical composition}

The cloud samples contained high concentrations of watersoluble ions at Mt. Tai. The dominant ions were nitrate, sulfate, ammonium and calcium with VWM concentrations of 56.4, 44.2, 34.2 and $5.9 \mathrm{mg} \mathrm{L}^{-1}$, respectively. These ions represented $88.1 \%$ of the total determined ion concentrations (TDIC). The concentrations of minor ions including chloride, potassium, sodium, magnesium and organic acids ranged from 0.7 to $4.1 \mathrm{mg} \mathrm{L}^{-1}$, only amounting to $10.6 \%$ of the TDIC. Because of the frequent agricultural and livestock activities near Mt. Tai, $\mathrm{NH}_{4}^{+}$was the predominant cation (Cai et al., 2015; Xu et al., 2015). Calcium was the second most abundant cation and likely originated from sandstorms and/or construction activities. The concentration of $\mathrm{SO}_{4}^{2-}$ amounted to $27.7 \%$ of the TDIC, which made $\mathrm{SO}_{4}^{2-}$ the second most abundant anion. The concentration of nonsea-salt sulfate (nss- $\mathrm{SO}_{4}^{2-}$ ) was calculated using the equation $\left[\mathrm{nss}-\mathrm{SO}_{4}^{2-}\right]=\left[\mathrm{SO}_{4}^{2-}\right]-0.2455\left[\mathrm{Na}^{+}\right]$. In this equation, it is assumed that the chemical properties of sea salt sulfate (ss$\mathrm{SO}_{4}^{2-}$ ) in particles are identical to those in sea water and the soluble $\mathrm{Na}^{+}$solely originates from sea salt (Morales et al., 1998). Through calculation, the $\mathrm{nss}-\mathrm{SO}_{4}^{2-}$ represented 93.5$100 \%$ of the total $\mathrm{SO}_{4}^{2-}$ in this study. Furthermore, this might be underestimated because soil dust and biomass combustion

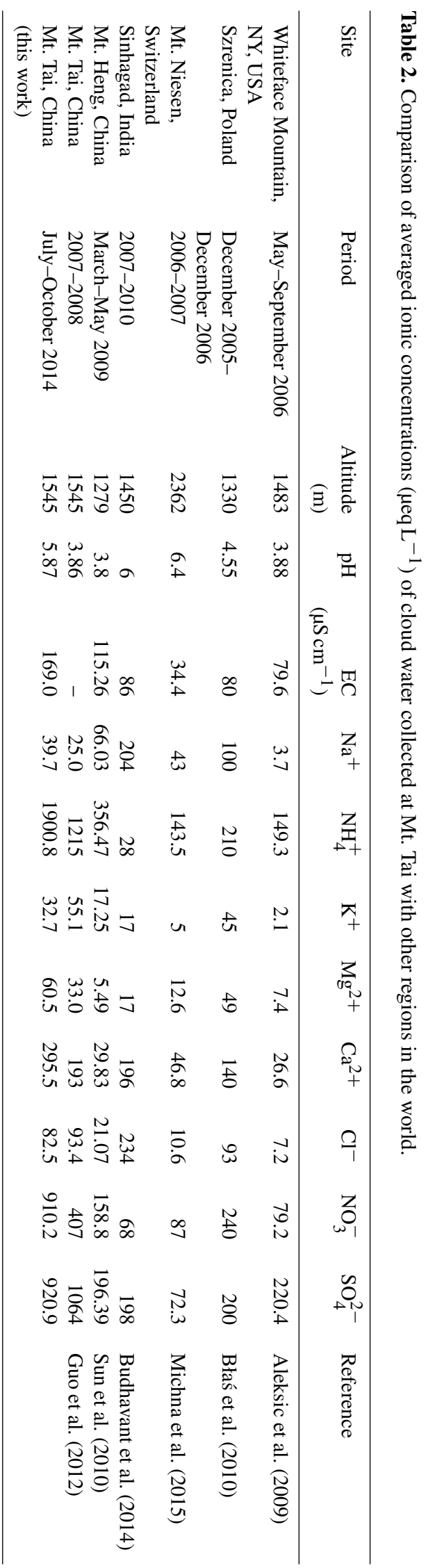


are also sources of $\mathrm{Na}^{+}$besides sea salts (Lu et al., 2010;

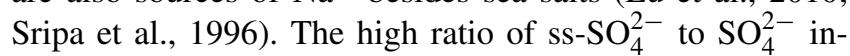
dicated that anthropogenic sulfur emissions were the main sources of $\mathrm{SO}_{4}^{2-}$ in the cloud samples at Mt. Tai. It should be noted that the VWM of the concentration of $\mathrm{SO}_{4}^{2-}$ was almost the same as that reported during 2007-2008, but the concentration of $\mathrm{NO}_{3}^{-}$increased significantly by a factor of 2.24 (Guo et al., 2012). This made $\mathrm{NO}_{3}^{-}$surpass $\mathrm{SO}_{4}^{2-}$ to be the predominant anion in 2014. Generally speaking, the previous research indicated that the scavenging of aerosol nitrate and the uptake of gaseous nitric acid are the main sources of nitrate in cloud/fog water (Collett Jr. et al., 2002). Our results imply that nitrate precursors (mainly $\mathrm{NO}_{x}$ from power plants and/or motor vehicles) had a substantial increase since 2007-2008.

Generally, the $\mathrm{pH}$ of cloud water is determined by the balance between the acid and the alkaline components. Two factors can decrease the acidity of cloud water: a large input of alkaline ions and/or a decrease in acid anions. Although the VWM concentration of $\mathrm{NO}_{3}^{-}$increased significantly, the additional increases in $\mathrm{NH}_{4}^{+}$and $\mathrm{Ca}^{2+}$ should also be noted. Especially for $\mathrm{NH}_{4}^{+}$, the VWM concentration of $\mathrm{NH}_{4}^{+}$increased since 2007-2008 by a factor of 1.56 (Guo et al., 2012). This may be attributable to the increasing use of agricultural fertilization and soil acidification (Cai et al., 2015; Xu et al., 2015). As a result, the increased levels of $\mathrm{NH}_{4}^{+}$and $\mathrm{Ca}^{2+}$ play a crucial role in neutralizing the soluble acid ions $\left(\mathrm{NO}_{3}^{-}\right.$ and $\mathrm{SO}_{4}^{2-}$ ) and decreasing the acidity of cloud water in 2014 .

The VWM concentrations of acetate, lactate, formate and oxalate were $4.1,3.0,1.75$ and $0.81 \mathrm{mg} \mathrm{L}^{-1}$, respectively, accounting for $7.01 \%$ of the TDIC. Based on the sources or source strengths of formic acid and acetic acid, the formicto-acetic acid ratio ( $\mathrm{F} / \mathrm{A}$ ) could be used as an indicator to determine the sources of organic acids (Sun et al., 2016; Tan et al., 2010). A low ratio indicated the important role of direct emissions (such as biomass emission, combustion activities and automobile exhaust) whereas a high ratio indicated the in situ photochemical generation of formic acid (Talbot et al., 1988; Tanner and Law, 2003). In the collected cloud samples, formic acid and acetic acid were highly correlated $(r=0.758, p \leq 0.01) . \mathrm{F} / \mathrm{A}$ was about 0.78 (less than 1 ), suggesting that direct emissions were important sources of organic acids (Kieber et al., 2002; Li et al., 2011). Oxalic acid was significantly correlated with formic acid $(r=0.667$, $p \leq 0.01)$ and acetic acid $(r=0.638, p \leq 0.01)$. This implied that formic acid, acetic acid and oxalic acid were probably emitted from the same sources and/or accumulated under similar physical conditions (Tanner and Law, 2003). No significant correlations were found between lactic acid and the other three carboxylic acids; no significant correlations were found between lactic acid and the other water-soluble ions in the cloud samples. This implied that the emission source of lactic acid was different from formic, acetic and oxalic acids.

\subsection{Microphysical properties of cloud water}

\subsubsection{Microphysical parameters}

The sampling period, number of cloud samples, mean level of $\mathrm{PM}_{2.5}$, mean microphysical parameters and meteorological conditions for each cloud event are summarized in Table 3. There was great diversity in the $N_{\mathrm{d}}$ and the LWC among the cloud events. The mean values of $N_{\mathrm{d}}$ ranged widely from 79 to $722 \mathrm{~cm}^{-3}$ and the mean values of LWC ranged widely from 0.01 to $0.39 \mathrm{~g} \mathrm{~m}^{-3}$. Orographic cloud is a highly heterogeneous system consisting of randomly distributed air volumes with different characteristics (Gonser et al., 2012). This feature of orographic cloud generally determines the large differences in CDSD, LWC and aerosol composition of different cloud events.

\subsubsection{Cloud droplet size distribution}

The CDSD, which indicates the dynamic and thermodynamic properties of a cloud system, is one of the most crucial determinants of the microstructures of cloud (Yin et al., 2011). To investigate the CDSD, four typical cloud events (labeled A, B, C and D) were studied in light of their mean $\mathrm{PM}_{2.5}$ levels of 81.6, 43.0, 25.0 and $11.1 \mu \mathrm{g} \mathrm{m}^{-3}$ for events A, B, C and D, respectively. As shown in Fig. 1, all of the cloud droplets in cloud samples were smaller than $26.0 \mu \mathrm{m}$. As the cloud processes continued, droplets ranging from 6.0 to $9.0 \mu \mathrm{m}$ became dominant. The ratios of cloud droplets with $6.0-9.0 \mu \mathrm{m}$ to all droplet sizes were relatively stable among the four cloud events (between $0.6: 1$ and $0.7: 1$ ). The maximum $N_{\mathrm{d}}$, which could reach over $1950 \mathrm{~cm}^{-3}$, always occurred at a droplet size of $7.0 \mu \mathrm{m}$.

An examination of the meteorological parameters with the microphysical properties of the clouds showed that the LWC somewhat influenced the CDSD. Higher LWC values increased the number of larger cloud droplets and broadened the droplet size distribution, while lower LWC values inhibited the formation of larger cloud droplets. The formation stage of cloud event B, which occurred during 01:30 02:40 UTC/GMT+8 on 23 August 2014, provided a clear example. At $02: 30$, the LWC was relatively low with a value of $0.09 \mathrm{~g} \mathrm{~m}^{-3}$. About $8.6 \%$ of the cloud droplets had diameters above $10.0 \mu \mathrm{m}$ and $27.6 \%$ had diameters below $5.0 \mu \mathrm{m}$. After $8 \mathrm{~min}$, the LWC sharply increased to $0.29 \mathrm{~g} \mathrm{~m}^{-3}$. The corresponding ratios were 16.3 and $17.1 \%$ for diameters below 10.0 and $5.0 \mu \mathrm{m}$, respectively. Moreover, cloud droplets larger than $16.0 \mu \mathrm{m}$ started to appear and the CDSD changed from a monomodal distribution to a weakly bimodal distribution. With the development of the cloud event, the standard deviation of the CDSD represented a positive correlation with LWC values. It showed that a high LWC could broaden the droplet size distribution and increase the range of cloud droplets. This situation also occurred in many other cloud events at Mt. Tai. 
Table 3. Description of monitored cloud events at Mt. Tai with monitoring times, number of samples (no. samples) and averaged values of liquid water content (LWC), median volume diameter (MVD), effective diameter (ED), number concentration $\left(N_{\mathrm{d}}\right)$, temperature $(T)$ and relative humidity $(\mathrm{RH})$.

\begin{tabular}{|c|c|c|c|c|c|c|c|c|c|c|c|}
\hline Event & $\begin{array}{l}\text { Start } \\
(\mathrm{UTC} / \mathrm{GMT}+8)\end{array}$ & $\begin{array}{l}\text { Stop } \\
(\mathrm{UTC} / \mathrm{GMT}+8)\end{array}$ & $\begin{array}{r}\text { No. } \\
\text { samples }\end{array}$ & $\begin{array}{r}\text { Duration } \\
\text { (h) }\end{array}$ & $\begin{array}{r}\mathrm{PM}_{2.5}{ }^{\mathrm{a}} \\
\left(\mu \mathrm{g} \mathrm{m}^{-3}\right)\end{array}$ & $\begin{array}{r}\mathrm{LWC}^{\mathrm{a}} \\
\left(\mathrm{g} \mathrm{m}^{-3}\right)\end{array}$ & $\begin{array}{r}N_{\mathrm{d}}^{\mathrm{a}} \\
\left(\mathrm{cm}^{-3}\right)\end{array}$ & $\begin{array}{r}\text { MVD }^{\mathrm{a}} \\
(\mu \mathrm{m})\end{array}$ & $\begin{array}{l}\mathrm{ED}^{\mathrm{a}} \\
(\mu \mathrm{m})\end{array}$ & $\begin{array}{r}T \\
\left({ }^{\circ} \mathrm{C}\right)\end{array}$ & $\begin{array}{r}\mathrm{RH}^{\mathrm{a}} \\
(\%)\end{array}$ \\
\hline 1 & 24 July 2014 08:30 & 24 July 2014 23:20 & 3 & 14.8 & 14.5 & 0.24 & 408 & 12.7 & 11.0 & $15.5-22.6$ & 97.9 \\
\hline 2 (D) & 25 July 2014 12:00 & 25 July 2014 21:40 & 2 & 9.7 & 11.1 & 0.18 & 719 & 8.3 & 8.3 & $13.6-14.6$ & 100.0 \\
\hline 3 & 26 July 2014 23:06 & 27 July 2014 05:13 & 0 & 6.1 & 100.7 & 0.04 & 211 & 7.8 & 7.4 & $15.7-17.0$ & 99.0 \\
\hline $4(\mathrm{~A})$ & 28 July 2014 22:40 b & 29 July 2014 04:00 & 1 & 5.3 & 81.6 & 0.09 & 337 & 8.2 & 7.8 & $16.5-17.6$ & 99.2 \\
\hline 5 & 29 July 2014 20:33 & 29 July 2014 22:20 & 0 & 1.8 & 65.6 & 0.14 & 694 & 7.8 & 7.6 & $18.5-18.9$ & 99.3 \\
\hline 6 & 30 July 2014 12:46 & 30 July 2014 13:50 & 1 & 1.1 & 13.2 & 0.21 & 308 & 12.6 & 11.8 & $16.8-18.5$ & 99.5 \\
\hline 7 (C) & 30 July 2014 20:20b & 30 July 2014 22:40 & 0 & 2.3 & 25.0 & 0.08 & 253 & 9.2 & 9.2 & $16.9-18.2$ & 99.6 \\
\hline 8 & 31 July 2014 19:11 & 1 August 2014 09:19 & 2 & 14.1 & 20.1 & 0.18 & 329 & 12.6 & 11.5 & $17.9-19.1$ & 99.5 \\
\hline 9 & 4 August 2014 23:42 & 5 August 2014 11:30 & 1 & 11.8 & 65.8 & 0.13 & 539 & 9.0 & 8.5 & $19.5-21.9$ & 99.3 \\
\hline 10 & 5 August 2014 18:45 & 6 August 2014 06:13 & 1 & 11.5 & 40.0 & 0.11 & 227 & 11.1 & 9.8 & $16.0-20.3$ & 99.3 \\
\hline 11 & 9 August 2014 07:41 & 9 August 2014 09:32 & 0 & 1.8 & 17.4 & 0.06 & 261 & 7.9 & 7.7 & $13.7-14.0$ & 100.0 \\
\hline 12 & 11 August 2014 20:42 & 11 August 2014 21:09 & 0 & 0.4 & 173.3 & 0.06 & 392 & 8.3 & 7.7 & $17.6-17.9$ & 99.7 \\
\hline 13 & 12 August 2014 23:04 & 13 August 2014 03:55 & 2 & 4.8 & 66.1 & 0.19 & 536 & 9.4 & 9.1 & $13.8-16.9$ & 99.0 \\
\hline 14 & 13 August 2014 18:58 & 14 August 2014 06:22 & 3 & 11.4 & 34.5 & 0.19 & 312 & 10.9 & 9.7 & $13.5-15.9$ & 98.4 \\
\hline 15 & 14 August 2014 17:35 & 14 August 2014 19:52 & 0 & 2.3 & 94.6 & 0.02 & 104 & 7.2 & 6.5 & $15.7-17.7$ & 98.8 \\
\hline 16 & 15 August 2014 18:52 & 16 August 2014 05:59 & 0 & 11.1 & 66.4 & 0.04 & 283 & 6.9 & 6.5 & $15.0-17.6$ & 99.2 \\
\hline 17 & 16 August 2014 19:45 & 17 August 2014 05:10 & 0 & 9.4 & 93.9 & 0.03 & 157 & 8.3 & 7.3 & $15.5-18.2$ & 98.4 \\
\hline 18 & 17 August 2014 10:02 & 17 August 2014 11:13 & 1 & 1.2 & 63.5 & 0.39 & 722 & 11.7 & 10.6 & $14.9-17.0$ & 99.2 \\
\hline 19 & 17 August 2014 21:57 & 18 August 2014 01:23 & 1 & 3.4 & 52.5 & 0.10 & 366 & 8.5 & 8.3 & $14.3-15.2$ & 99.1 \\
\hline 20 & 18 August 2014 08:42 & 18 August 2014 11:05 & 0 & 2.4 & - & 0.03 & 118 & 7.2 & 6.8 & $15.0-16.5$ & 98.4 \\
\hline 21 & 21 August 2014 20:00 & 22 August 2014 13:48 & 0 & 17.8 & 57.9 & 0.02 & 109 & 7.0 & 6.5 & $15.9-20.7$ & 96.3 \\
\hline $22(\mathrm{~B})$ & 23 August 2014 01:30 & 23 August 2014 09:20 & 3 & 7.8 & 43.0 & 0.21 & 624 & 9.6 & 9.4 & $16.2-17.4$ & 99.6 \\
\hline 23 & 23 August 2014 18:12 & 23 August 2014 19:54 & 0 & 1.7 & 70.6 & 0.01 & 88 & 6.8 & 6.3 & $16.8-17.8$ & 99.5 \\
\hline 24 & 25 August 2014 02:25 & 25 August 2014 06:40 & 0 & 4.2 & 29.4 & 0.01 & 79 & 5.7 & 5.3 & $13.8-15.0$ & 97.8 \\
\hline
\end{tabular}

${ }^{a}$ The arithmetic mean value. ${ }^{\mathrm{b}}$ The selected four typical cloud events according to the average $\mathrm{PM}_{2.5}$ level for 28 July $201422: 40$ to $29 \mathrm{July} 2014$ 04:00 (event A, $81.6 \mu \mathrm{g} \mathrm{m}^{-3}$ ),

23 August 2014 01:30 to 23 August 2014 09:20 (event B, $43.0 \mu \mathrm{g} \mathrm{m}^{-3}$ ), 30 July 2014 20:20 to 30 July 2014 22:40 (event C, $25.0 \mu \mathrm{g} \mathrm{m}^{-3}$ ) and $25 \mathrm{July}^{2014} 12: 00$ to 25 July $201421: 40$ (event $\mathrm{D}, 11.1 \mathrm{\mu g} \mathrm{m}^{-3}$ ).

\subsubsection{Cloud scavenging effect}

Cloud processes together with wet deposition play crucial roles in scavenging atmospheric aerosols. Based on the initial $\mathrm{PM}_{2.5}$ levels, cloud processes can be classified into two types: type I (including events A and B), which have high initial $\mathrm{PM}_{2.5}$ levels, and type II (including events $\mathrm{C}$ and $\mathrm{D}$ ), which have low initial $\mathrm{PM}_{2.5}$ levels.

Type I cloud processes have high levels of aerosol scavenging activity. Using event $\mathrm{A}$ as an example, at the beginning of the cloud process, there was a relatively high level of $\mathrm{PM}_{2.5}$ (approximately $128 \mu \mathrm{g} \mathrm{m}^{-3}$ ) and $N_{\mathrm{d}}$ increased sharply from 6 to $437 \mathrm{~cm}^{-3}$ over $1 \mathrm{~min}$. As the cloud process continued, the level of $\mathrm{PM}_{2.5}$ decreased and then fluctuated with a mean concentration of $78.2 \mu \mathrm{g} \mathrm{m}^{-3}$. About $30 \mathrm{~min}$ later, the $N_{\mathrm{d}}$ reached a maximum with $1538 \mathrm{~cm}^{-3}$ and the level of $\mathrm{PM}_{2.5}$ reached a minimum with $23.9 \mu \mathrm{g} \mathrm{m}^{-3}$, which indicated a high $\mathrm{PM}_{2.5}$ removal efficiency of $81.3 \%$. The somewhat inverse relationship between $N_{\mathrm{d}}$ and the level of $\mathrm{PM}_{2.5}$ reflects the efficient pollutant removal effect of cloud formation. In type II cloud processes, the levels of $\mathrm{PM}_{2.5}$ were relatively low at the initial stage. But for both types of cloud events, the $N_{\mathrm{d}}$ significantly decreased and the $\mathrm{PM}_{2.5}$ levels evidently increased as cloud events began to dissipate. This may be due to the evaporation of water content that con- densed on the particles, which freed the $\mathrm{CCN}$ and formed haze. This confirmed that $\mathrm{PM}_{2.5}$ was one of the important types of $\mathrm{CCN}$ at Mt. Tai. So, $\mathrm{PM}_{2.5}$ mass concentration was used as a proxy for $\mathrm{CCN}$ number concentration in this study.

\subsection{Interaction between aerosols and cloud chemical properties}

As illustrated in Fig. 2, the TDIC was strongly correlated with the levels of $\mathrm{PM}_{2.5}$. High levels of $\mathrm{PM}_{2.5}$ normally lead to high TDIC, whereas low levels of $\mathrm{PM}_{2.5}$ usually lead to low TDIC. The $\mathrm{pH}$ values of cloud samples were somewhat affected by the concentrations of $\mathrm{PM}_{2.5}$. The lower $\mathrm{pH}$ values were likely to occur at higher concentrations of $\mathrm{PM}_{2.5}$. Generally, changes to the solute concentrations in cloud water can be caused by a combination of factors such as the microphysical conditions, the $\mathrm{CCN}$ properties, the chemical reactions in the cloud droplets and the gas-liquid phase equilibrium (van Pinxteren et al., 2016). Our data emphasize the crucial effect of $\mathrm{PM}_{2.5}$ on the changes in ion concentrations. $\mathrm{PM}_{2.5}$ is likely to be the main source of ions in cloud water.

To understand the exchange and variation of the three major ions $\left(\mathrm{SO}_{4}^{2-}, \mathrm{NO}_{3}^{-}\right.$and $\left.\mathrm{NH}_{4}^{+}\right)$between the aerosol phase and the cloud phase at the summit of Mt. Tai, we analyzed three cloud samples (CE-Aug23\#1 during 02:30 

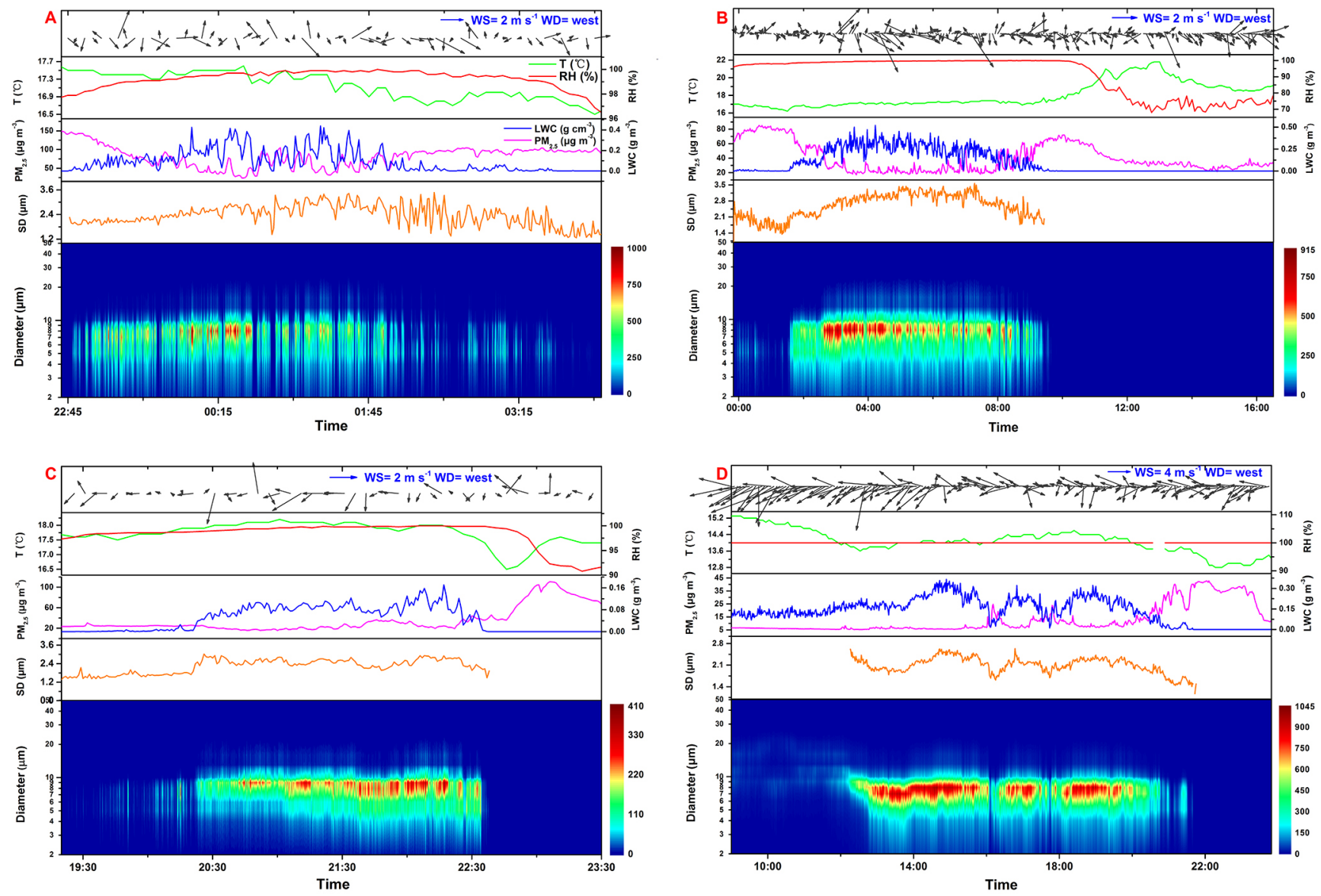

Figure 1. The variation of wind speed (WS, $\mathrm{m} \mathrm{s}^{-1}$ ), wind direction $(\mathrm{WD})$, temperature $\left(\mathrm{T},{ }^{\circ} \mathrm{C}\right)$, relative humidity $(\mathrm{RH}, \%), \mathrm{PM}_{2.5}$ level $\left(\mu \mathrm{g} \mathrm{cm}^{-3}\right)$, liquid water content (LWC, $\mathrm{g} \mathrm{m}^{-3}$ ), standard deviation of cloud droplet size distribution (SD, $\left.\mu \mathrm{m}\right)$ and cloud droplet number concentration (CDNC, $\mathrm{cm}^{-3}$ ) during four typical cloud events: (a) event A (28 July 2014 22:40 to 29 July 2014 04:00), (b) event B (23 August 2014 01:30 to 23 August 2014 09:20), (c) event C (30 July 2014 20:20 to 30 July 2014 22:40) and (d) event D (25 July 2014 12:00 to 25 July 2014 21:40).

04:38, CE-Aug23\#2 during 04:38-06:21 and CE-Aug23\#3 during 06:21-09:20) that were collected from the same cloud event (event B on 23 August 2014). As shown in Fig. 3, in the aerosol phase, the concentrations of $\mathrm{SO}_{4}^{2-}, \mathrm{NO}_{3}^{-}$and $\mathrm{NH}_{4}^{+}$decreased with increases in $\mathrm{LWC}$ and vice versa. In the cloud phase, high LWC values meant large cloud droplets and low concentrations of major ions while low $\mathrm{LWC}$ values induced small cloud droplets with high levels of $\mathrm{SO}_{4}^{2-}, \mathrm{NO}_{3}^{-}$ and $\mathrm{NH}_{4}^{+}$. Elbert et al., (2000) also observed an inverse relationship between the ion concentrations and the LWC values. Between CE-Aug23\#1 and CE-Aug23\#2, the ion concentrations decreased by factors of $2.29,2.07$ and 1.51 for $\mathrm{SO}_{4}^{2-}$, $\mathrm{NO}_{3}^{-}$and $\mathrm{NH}_{4}^{+}$, respectively. Meanwhile, the LWC increased from 0.04 to $0.32 \mathrm{~g} \mathrm{~m}^{-3}$ and the ED increased from 6.7 to $10.2 \mu \mathrm{m}$. At the dissipation stage of the cloud event, the LWC decreased to less than $0.10 \mathrm{~g} \mathrm{~m}^{-3}$ and the ED shrank to about $6.6 \mu \mathrm{m}$. Simultaneously, the ion concentrations significantly increased by factors of $1.56,1.18$ and 1.40 for $\mathrm{SO}_{4}^{2-}, \mathrm{NO}_{3}^{-}$ and $\mathrm{NH}_{4}^{+}$, respectively.

The above results demonstrate that cloud water is an important sink of soluble ions in the atmosphere and small cloud droplets tend to contain higher concentrations of soluble ions than larger ones. $\mathrm{SO}_{4}^{2-}, \mathrm{NO}_{3}^{-}$and $\mathrm{NH}_{4}^{+}$in the aerosol phase were primarily assumed to be transferred to the cloud phase. However, the concentrations of the soluble components in the cloud phase could not be accurately predicted if only based on their concentrations in the aerosol phase, as the strong dilution effect of the cloud-water content must also be considered. The concentrations of ions in the cloud phase were primarily determined by two factors: the sources of the ions (i.e., the corresponding ion concentrations in the particles acted as CCN) and the LWC values (which represents the dilution effect of the cloud water). The similar variation trends of $\mathrm{SO}_{4}^{2-}, \mathrm{NO}_{3}^{-}$and $\mathrm{NH}_{4}^{+}$in both the aerosol phase and the cloud phase confirmed that LWC was an important factor affecting the ion concentrations in the cloud water at Mt. Tai 


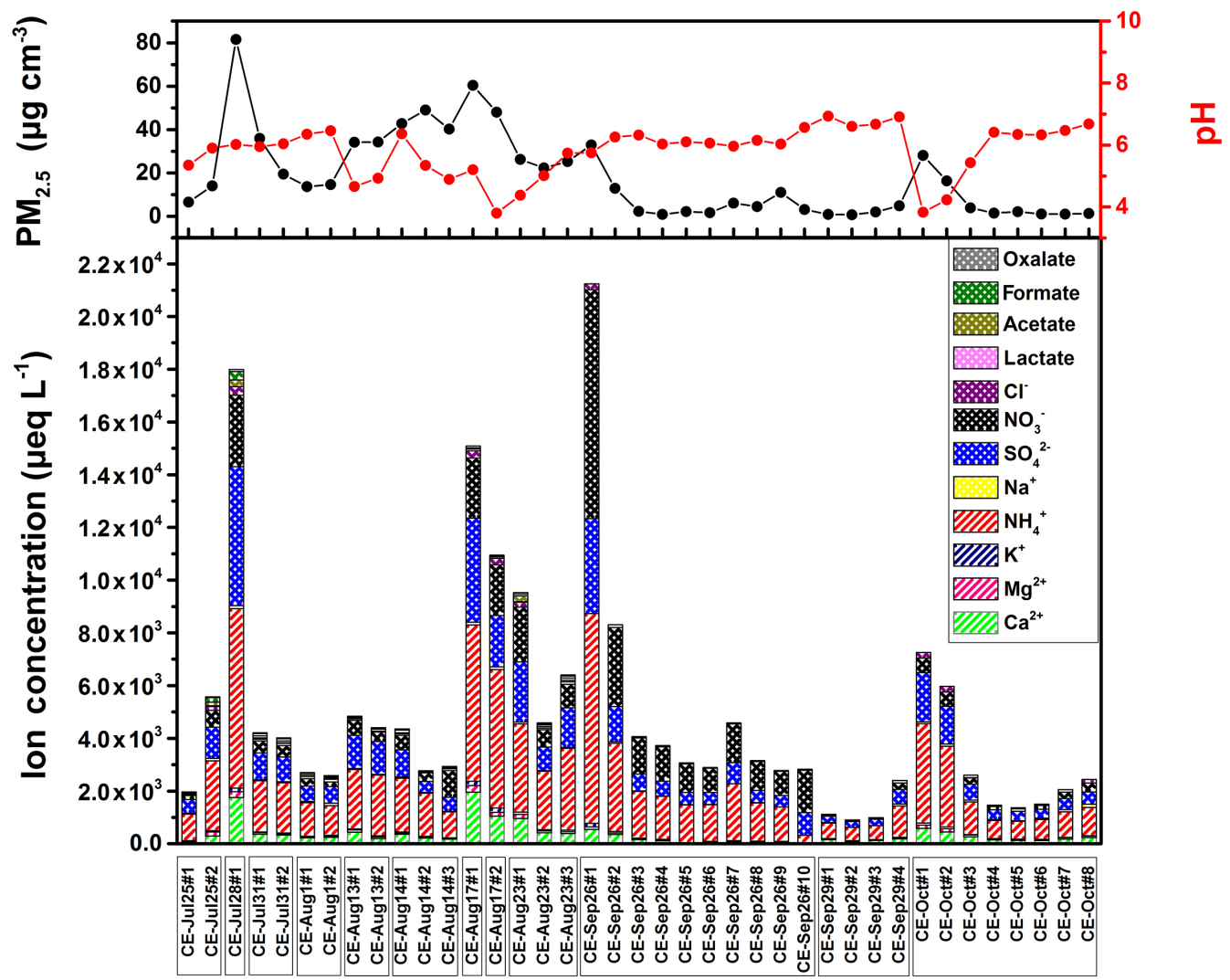

Figure 2. Ion and organic acid concentrations $\left(\mu \mathrm{eq} \mathrm{L}^{-1}\right)$ with the variation of $\mathrm{PM}_{2.5}$ levels $\left(\mu \mathrm{g} \mathrm{cm}^{-3}\right)$ and $\mathrm{pH}$ of cloud-water samples.

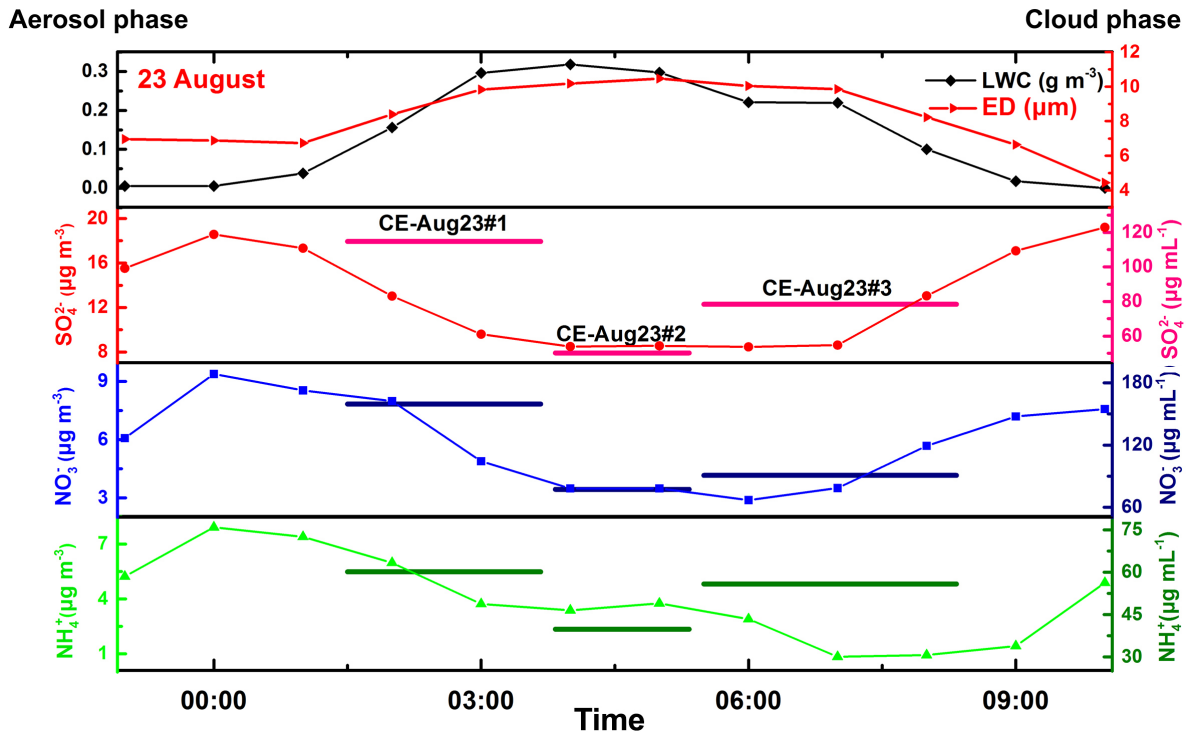

Figure 3. Variation trend of hour-averaged $\mathrm{LWC}\left(\mathrm{g} \mathrm{m}^{-3}\right), \mathrm{ED}(\mu \mathrm{m})$ and the concentrations of $\mathrm{NO}_{3}^{-}, \mathrm{SO}_{4}^{2-}$ and $\mathrm{NH}_{4}^{+}$in the aerosol phase and the cloud phase during the cloud event on 23 August 2014. 
(Aleksic and Dukett, 2010; Elbert et al., 2000). As mentioned above, LWC also determined the size of cloud droplets. This ultimately showed that high concentrations of soluble ions are concentrated in small cloud droplets. It should be noted that, compared with $\mathrm{SO}_{4}^{2-}$ and $\mathrm{NO}_{3}^{-}$, the concentration of $\mathrm{NH}_{4}^{+}$in the aerosol phase did not directly increase at the dissipation stage of the cloud event. This was primarily due to the high solubility of $\mathrm{NH}_{3}$, which dissolved in the cloud water and gave rise to the increase in the concentration of $\mathrm{NH}_{4}^{+}$ in cloud samples.

\subsection{Water-soluble ions and droplet size under $\mathbf{P M}_{2.5}$}

Secondary inorganic compounds especially ammonium sulfate and ammonium nitrate were the main hygroscopic compounds of particulate matter. The presence of these compounds could enhance the hygroscopic ability of atmospheric particles and facilitate their ability to act as CCN (Wang et al., 2014; Ye et al., 2011). These water-soluble ions are primarily transferred to the cloud phase during the formation of cloud droplets by activation of $\mathrm{CCN}$. As mentioned before, $\mathrm{SO}_{4}^{2-}, \mathrm{NO}_{3}^{-}, \mathrm{NH}_{4}^{+}$and $\mathrm{Ca}^{2+}$ were the most predominant ions in cloud samples collected at Mt. Tai. The averaged concentrations surpassed $88.1 \%$ of the TDIC. Presumably, $\mathrm{PM}_{2.5}$ was the main source of the mentioned soluble ions in cloud water. In order to investigate the trend between watersoluble ions and cloud droplet size under different $\mathrm{PM}_{2.5}$ levels, 17 cloud samples collected from 25 July to 23 August were studied as shown in Fig. 4. As can be seen, high $\mathrm{PM}_{2.5}$ levels represented high ion concentrations and small cloud droplets. This confirmed again that $\mathrm{PM}_{2.5}$ acting as $\mathrm{CCN}$ was the main source of soluble ions in cloud water. High $\mathrm{PM}_{2.5}$ levels would lead to a large source of $\mathrm{CCN}$, increase the competition of ambient water vapor and hinder the formation of large cloud droplets.

It should be noticed that sometimes the $N_{\mathrm{d}}$ varied at the same $\mathrm{PM}_{2.5}$ level in Fig. 4b. This was caused by the variation of LWC values or ambient $\mathrm{RH}$ in different monitoring moments (Ackerman et al., 2004). The low RH (representing insufficient water vapor in the atmosphere) would impede the hygroscopic growth of particles and the activation of droplets (Gonser et al., 2012; Liu et al., 2011), affecting the formation of cloud droplets.

\section{Conclusions}

In 2014, samples of clouds at Mt. Tai showed that the VWM $\mathrm{pH}$ of the cloud samples was 5.87. It is much higher than that reported by previous studies taking place at the same site during 2007-2008. The cloud water contained much higher concentrations of ions than the samples collected at other orographic sites, indicating the strong influence of anthropogenic emissions on clouds at the summit of Mt. Tai. The dominant ion species were $\mathrm{NH}_{4}^{+}, \mathrm{SO}_{4}^{2-}, \mathrm{Ca}^{2+}$ and $\mathrm{NO}_{3}^{-}$,

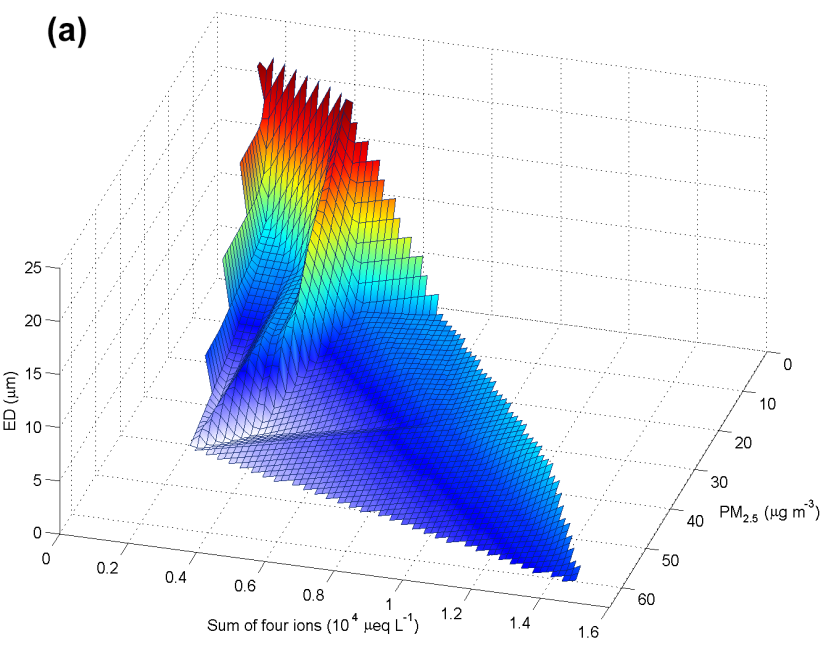

(b)

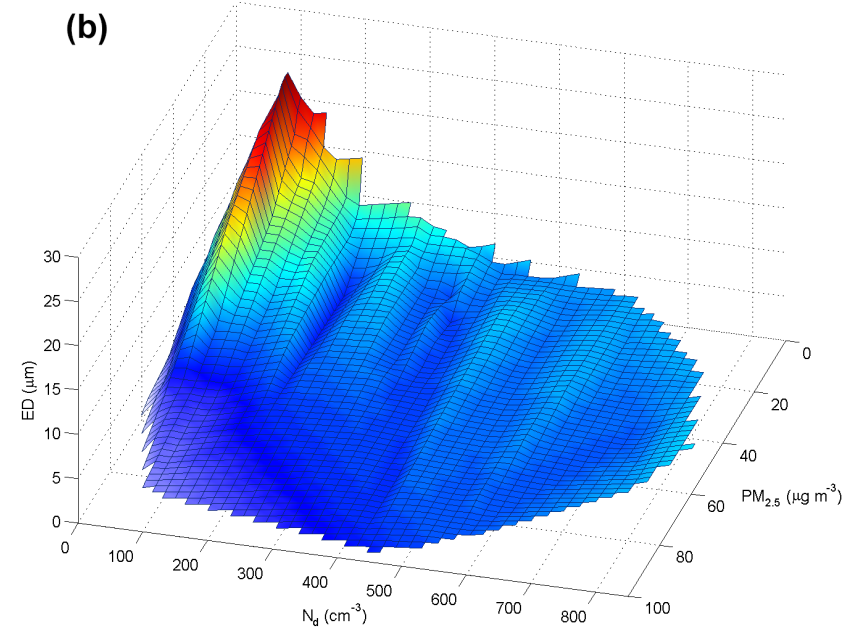

Figure 4. (a) The variation of the ED of cloud droplets and the sum of four water-soluble ions $\left(\mathrm{SO}_{4}^{2-}, \mathrm{NO}_{3}^{-}, \mathrm{NH}_{4}^{+}\right.$and $\left.\mathrm{Ca}^{2+}\right)$ under different $\mathrm{PM}_{2.5}$ levels. (b) The variation of the ED and $N_{\mathrm{d}}$ of cloud droplets under different $\mathrm{PM}_{2.5}$ levels.

which amounted to more than $88.1 \%$ of the TDIC. The $\mathrm{NO}_{3}^{-}$content of the cloud water was significantly higher than that during 2007-2008. However, the increase in the $\mathrm{NH}_{4}^{+}$concentration (mainly from $\mathrm{NH}_{3}$ ) exceeded that of $\mathrm{NO}_{3}^{-}$(mainly from $\mathrm{NO}_{x}$ ), leading to net neutralization and reduced cloud acidity. The rapid increase in the concentration of $\mathrm{NH}_{4}^{+}$should be attributable to agricultural fertilization and soil acidification which frequently occurred during recent years (Cai et al., 2015; Xu et al., 2016). The microphysical parameters of the cloud samples varied enormously between the cloud events. The cloud droplets were all smaller than $26.0 \mu \mathrm{m}$ and most were 6.0-9.0 $\mu \mathrm{m}$. The maximum $N_{\mathrm{d}}$ was associated with droplet sizes of $7.0 \mu \mathrm{m}$. Higher LWC values could facilitate the formation of larger cloud droplets and broadened the droplet size distribution. A strong interac- 
(a) High $\mathrm{PM}_{2.5}$ level $\left(\mathrm{PM}_{2.5}>35 \mu \mathrm{g} \mathrm{m}^{-3}\right)$

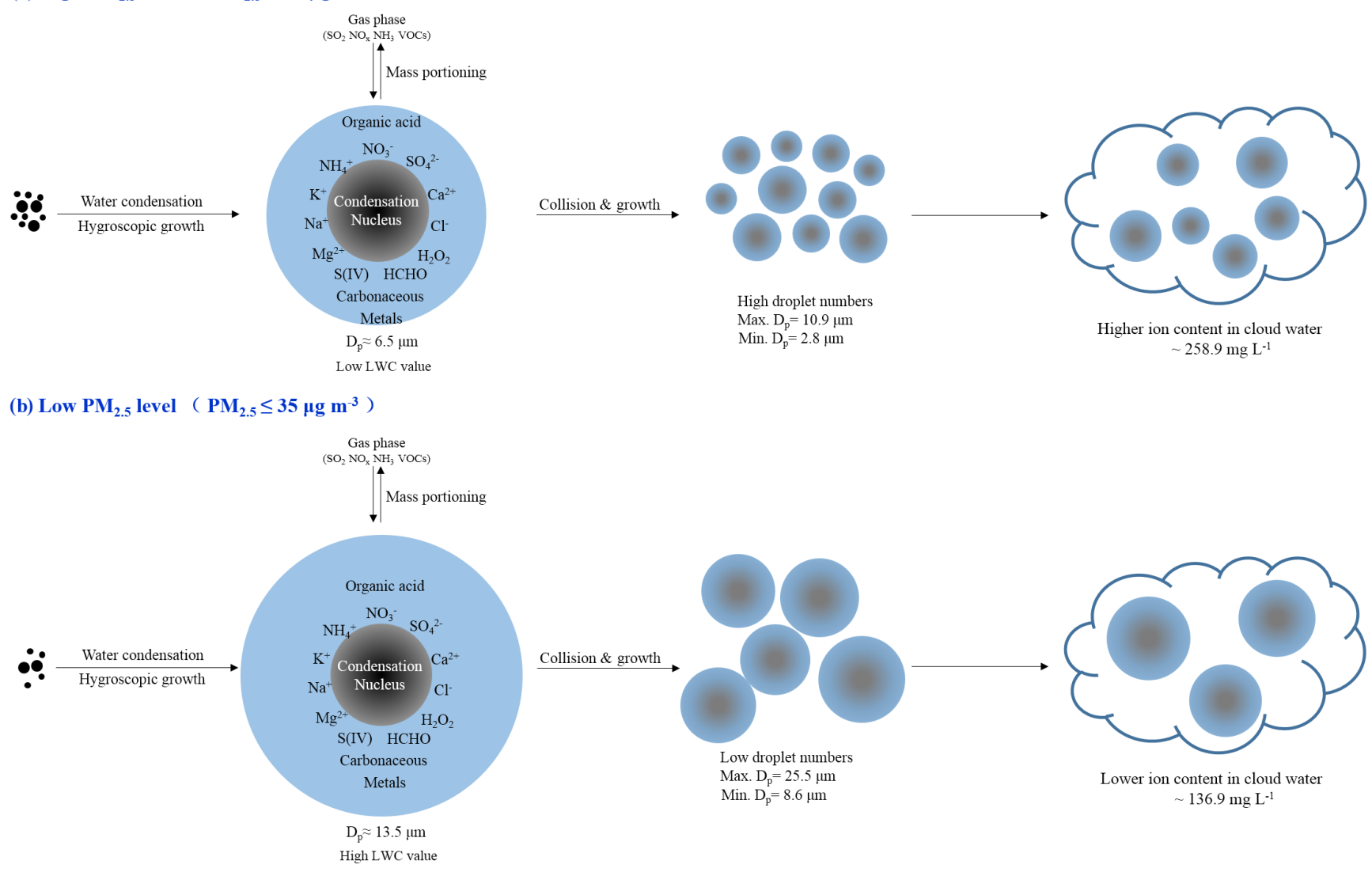

Figure 5. A schematic of aerosol particles' impact on the cloud droplet sizes. (a) $\mathrm{PM}_{2.5}>35 \mu \mathrm{g} \mathrm{m}^{-3}$, (b) $\mathrm{PM}_{2.5} \leq 35 \mu \mathrm{g} \mathrm{m}{ }^{-3}$.

tion was observed between the concentrations of soluble ions in cloud droplets and the levels of $\mathrm{PM}_{2.5}$ in the atmosphere. The clouds played a crucial role in scavenging atmospheric aerosols. Higher $\mathrm{PM}_{2.5}$ levels resulted in higher TDIC. The lower $\mathrm{pH}$ values were likely to occur at higher $\mathrm{PM}_{2.5}$ concentrations. We found that the dilution effect of cloud water was strong and it should not be ignored when estimating concentrations of soluble components in the cloud phase.

In summary, the mechanism of cloud droplet formation is summarized in Fig. 5. According to the concentrations of $\mathrm{PM}_{2.5}$, cloud events were divided into two categories: one was the $\mathrm{PM}_{2.5}$ concentrations greater than $35 \mu \mathrm{g} \mathrm{m}^{-3}$ and the other was the $\mathrm{PM}_{2.5}$ concentrations less than or equal to $35 \mu \mathrm{g} \mathrm{m}{ }^{-3}$. Cloud droplets would be formed on condensation nuclei (usually aerosols including secondary aerosol, dust, sea salt, etc.) through water vapor condensation and then undergo hygroscopic growth. The soluble ions in condensation nuclei and ambient gases could enter cloud droplets through surface reactions and consequently participate in dissolution, diffusion, dilution and aqueous reactions in the cloud phase. Higher aerosol concentrations supplied higher concentrations of soluble ions for cloud droplets and facilitated the formation of smaller sizes of cloud droplets, which caused the high concentrations of soluble ions in small cloud droplets.

Data availability. The data for studying chemical and microphysical properties of cloud in this article are available from the authors upon request (jrli@mail.sdu.edu.cn).

Competing interests. The authors declare that they have no conflict of interest.

Special issue statement. This article is part of the special issue "Regional transport and transformation of air pollution in eastern China". It is not associated with a conference.

Acknowledgements. This work was supported by the Taishan Scholar grant (ts20120552), the National Natural Science Foundation of China (41375126, 41275123, 21190053, 21177025), the Cyrus Tang Foundation (no. CTF-FD2014001), the Ministry of Science and Technology of China (2016YFC0202701, 2014BAC22B01), the Strategic Priority Research Program of 
the Chinese Academy of Sciences (grant no. XDB05010200), and the Natural Science Foundation of Shandong Province (no. ZR2014BQ031).

Edited by: Hang Su

Reviewed by: two anonymous referees

\section{References}

Ackerman, A. S., Kirkpatrick, M. P., Stevens, D. E., and Toon, O. B.: The impact of humidity above stratiform clouds on indirect aerosol climate forcing, Nature, 432, 1014-1017, 2004.

Aleksic, N. and Dukett, J. E.: Probabilistic relationship between liquid water content and ion concentrations in cloud water, Atmos. Res., 98, 400-405, 2010.

Aleksic, N., Roy, K., Sistla, G., Dukett, J., Houck, N., and Casson, P.: Analysis of cloud and precipitation chemistry at Whiteface Mountain, NY, Atmos. Environ., 43, 2709-2716, 2009.

Błaś, M., Sobik, M., and Twarowski, R.: Changes of cloud water chemical composition in the Western Sudety Mountains, Poland, Atmos. Res., 87, 224-231, 2008.

Błaś, M., Polkowska, Ż., Sobik, M., Klimaszewska, K., Nowiński, K., and Namieśnik, J.: Fog water chemical composition in different geographic regions of Poland, Atmos. Res., 95, 455-469, 2010.

Borys, R. D., Lowenthal, D. H., and Mitchell, D. L.: The relationships among cloud microphysics, chemistry, and precipitation rate in cold mountain clouds, Atmos. Environ., 34, 2593-2602, 2000.

Budhavant, K. B., Rao, P. S. P., Safai, P. D., Granat, L., and Rodhe, H.: Chemical composition of the inorganic fraction of cloudwater at a high altitude station in West India, Atmos. Environ., 88, 59-65, 2014.

Cai, Z., Wang, B., Xu, M., Zhang, H., He, X., Zhang, L., and Gao, S.: Intensified soil acidification from chemical $\mathrm{N}$ fertilization and prevention by manure in an 18-year field experiment in the red soil of southern China, J. Soils Sediments, 15, 260-270, 2015.

Collett Jr., J. L., Hoag, K. J., Sherman, D. E., Bator, A., and Richards, L. W.: Spatial and temporal variations in San Joaquin Valley fog chemistry, Atmos. Environ., 33, 129-140, 1998.

Collett Jr., J. L., Bator, A., Sherman, D. E., Moore, K. F., Hoag, K. J., Demoz, B. B., Rao, X., and Reilly, J. E.: The chemical composition of fogs and intercepted clouds in the United States, Atmos. Res., 64, 29-40, 2002.

Demoz, B. B., Collett Jr., J. L., and Daube Jr., B. C.: On the Caltech Active Strand Cloudwater Collectors, Atmos. Res., 41, 47-62, 1996.

DROPLET MEASUREMENT TECHNOLOGIES, I.: Particle Analysis and Display System (PADS) 3.6.3 Overview Manual DOC-0300, Rev C-11, 2012.

Elbert, W., Hoffmann, M. R., Krämer, M., Schmitt, G., and Andreae, M. O.: Control of solute concentrations in cloud and fog water by liquid water content, Atmos. Environ., 34, 1109-1122, 2000

Gonser, S. G., Klemm, O., Griessbaum, F., Chang, S. C., Chu, H. S., and Hsia, Y. J.: The Relation Between Humidity and Liquid Water Content in Fog: An Experimental Approach, Pure Appl. Geophys., 169, 1-13, 2012.
Gultepe, I. and Milbrandt, J. A.: Microphysical Observations and Mesoscale Model Simulation of a Warm Fog Case during FRAM Project, Pure Appl. Geophys., 164, 1161-1178, 2007.

Guo, J., Wang, Y., Shen, X., Wang, Z., Lee, T., Wang, X., Li, P., Sun, M., Collett Jr., J. L., Wang, W., and Wang, T.: Characterization of cloud water chemistry at Mount Tai, China: Seasonal variation, anthropogenic impact, and cloud processing, Atmos. Environ., 60, 467-476, 2012.

Herckes, P., Lee, T., Trenary, L., Kang, G., Chang, H., and Collett Jr., J. L.: Organic matter in central California radiation fogs, Environ. Sci. Technol., 36, 4777-4782, 2002.

Khan, A. J., Swami, K., Ahmed, T., Bari, A., Shareef, A., and Husain, L.: Determination of elemental carbon in lake sediments using a thermal-optical transmittance (TOT) method, Atmos. Environ., 43, 5989-5995, 2009.

Kieber, R. J., Peake, B., Willey, J. D., and Avery, G. B.: Dissolved organic carbon and organic acids in coastal New Zealand rainwater, Atmos. Environ., 36, 3557-3563, 2002.

Kim, M.-G., Lee, B.-K., and Kim, H.-J.: Cloud/Fog Water Chemistry at a High Elevation Site in South Korea, J. Atmos. Chem., 55, 13-29, 2006.

Lee, A. K. Y., Hayden, K. L., Herckes, P., Leaitch, W. R., Liggio, J., Macdonald, A. M., and Abbatt, J. P. D.: Characterization of aerosol and cloud water at a mountain site during WACS 2010: secondary organic aerosol formation through oxidative cloud processing, Atmos. Chem. Phys., 12, 7103-7116, https://doi.org/10.5194/acp-12-7103-2012, 2012.

Li, P., Li, X., Yang, C., Wang, X., Chen, J., and Collett Jr., J. L.: Fog water chemistry in Shanghai, Atmos. Environ., 45, 4034-4041, 2011.

Liu, P. F., Zhao, C. S., Göbel, T., Hallbauer, E., Nowak, A., Ran, L., Xu, W. Y., Deng, Z. Z., Ma, N., Mildenberger, K., Henning, S., Stratmann, F., and Wiedensohler, A.: Hygroscopic properties of aerosol particles at high relative humidity and their diurnal variations in the North China Plain, Atmos. Chem. Phys., 11, 3479-3494, https://doi.org/10.5194/acp-11-3479-2011, 2011.

Lu, C., Niu, S., Tang, L., Lv, J., Zhao, L., and Zhu, B.: Chemical composition of fog water in Nanjing area of China and its related fog microphysics, Atmos. Res., 97, 47-69, 2010

Marinoni, A., Laj, P., Sellegri, K., and Mailhot, G.: Cloud chemistry at the Puy de Dôme: variability and relationships with environmental factors, Atmos. Chem. Phys., 4, 715-728, https://doi.org/10.5194/acp-4-715-2004, 2004.

Michna, P., Werner, R. A., and Eugster, W.: Does fog chemistry in Switzerland change with altitude?, Atmos. Res., 151, 31-44, 2015.

Miles, N. L., Verlinde, J., and Clothiaux, E. E.: Cloud Droplet Size Distributions in Low-Level Stratiform Clouds, J. Atmos. Sci., 57, 295-311, 2000.

Moore, K. F., Sherman, D. E., Reilly, J. E., Hannigan, M. P., Lee, T., and Collett, J. L.: Drop size-dependent chemical composition of clouds and fogs. Part II: Relevance to interpreting the aerosol/trace gas/fog system, Atmos. Environ., 38, 1403-1415, 2004.

Morales, J. A., Pirela, D., Nava, M. G. D., Borrego, B. Z. S. D., Velásquez, H., and Durán, J.: Inorganic water soluble ions in atmospheric particles over Maracaibo Lake Basin in the western region of Venezuela, Atmos. Res., 46, 307-320, 1998. 
Ogawa, N., Kikuchi, R., Okamura, T., Inotsume, J., Adzuhata, T., Ozeki, T., and Kajikawa, M.: Evaluation of ionic pollutants in cloud droplets at a mountain ridge in northern Japan using constrained oblique rotational factor analysis, Atmos. Res., 54, 279283, 2000.

Portin, H., Leskinen, A., Hao, L., Kortelainen, A., Miettinen, P., Jaatinen, A., Laaksonen, A., Lehtinen, K. E. J., Romakkaniemi, S., and Komppula, M.: The effect of local sources on particle size and chemical composition and their role in aerosol-cloud interactions at Puijo measurement station, Atmos. Chem. Phys., 14, 6021-6034, https://doi.org/10.5194/acp-14-6021-2014, 2014.

Ravishankara, A. R.: Heterogeneous and Multiphase Chemistry in the Troposphere, Science, 276, 1058-1065, 1997.

Schell, D., Wobrock, W., Maser, R., Preiss, M., Jaeschke, W., Georgii, H. W., Gallagher, M. W., Bower, K. N., Beswick, K. M., and Pahl, S.: The size-dependent chemical composition of cloud droplets, Atmos. Environ., 31, 2561-2576, 1997.

Sripa, P., Tongraar, A., and Kerdcharoen, T.: Chemical composition of fogwater in an urban area: Strasbourg (France), Environ. Pollut., 94, 345-354, 1996.

Sun, M., Wang, Y., Wang, T., Fan, S., Wang, W., Li, P., Guo, J., and Li, Y.: Cloud and the corresponding precipitation chemistry in south China: Water-soluble components and pollution transport, J. Geophys. Res.-Atmos., 115, D22303, https://doi.org/10.1029/2010JD014315, 2010.

Sun, X., Wang, Y., Li, H., Yang, X., Sun, L., Wang, X., Wang, T., and Wang, W.: Organic acids in cloud water and rainwater at a mountain site in acid rain areas of South China, Environ. Sci. Pollut. R., 23, 9529, https://doi.org/10.1007/s11356-016-6038-1, 2016.

Talbot, R. W., Beecher, K. M., Harriss, R. C., and Iii, W. R. C.: Atmospheric Geochemistry of Formic and Acetic Acids at a MidLatitude Temperate Site, J. Geophys. Res.-Atmos., 93, 16381652, 1988.

Tan, Y., Carlton, A. G., Seitzinger, S. P., and Turpin, B. J.: SOA from methylglyoxal in clouds and wet aerosols: Measurement and prediction of key products, Atmos. Environ., 44, 5218-5226, 2010.

Tanner, P. A. and Law, P. T.: Organic Acids in the Atmosphere and Bulk Deposition of Hong Kong, Water Air Soil Pollut., 142, 279297, 2003.

van Pinxteren, D., Fomba, K. W., Mertes, S., Müller, K., Spindler, G., Schneider, J., Lee, T., Collett, J. L., and Herrmann, H.: Cloud water composition during HCCT-2010: Scavenging efficiencies, solute concentrations, and droplet size dependence of inorganic ions and dissolved organic carbon, Atmos. Chem. Phys., 16, 3185-3205, https://doi.org/10.5194/acp-16-3185-2016, 2016.
Wang, X., Ye, X., Chen, H., Chen, J., Yang, X., and Gross, D. S.: Online hygroscopicity and chemical measurement of urban aerosol in Shanghai, China, Atmos. Environ., 95, 318-326, 2014.

Wang, Y., Wai, K. M., Gao, J., Liu, X., Wang, T., and Wang, W.: The impacts of anthropogenic emissions on the precipitation chemistry at an elevated site in North-eastern China, Atmos. Environ., 42, 2959-2970, 2008.

Wang, Y., Guo, J., Wang, T., Ding, A., Gao, J., Yang, Z., Collett, J. L., and Wang, W.: Influence of regional pollution and sandstorms on the chemical composition of cloud/fog at the summit of Mt. Taishan in northern China, Atmos. Res., 99, 434-442, 2011.

Watanabe, K., Honoki, H., Iwai, A., Tomatsu, A., Noritake, K., Miyashita, N., Yamada, K., Yamada, H., Kawamura, H., and Aoki, K.: Chemical Characteristics of Fog Water at Mt. Tateyama, Near the Coast of the Japan Sea in Central Japan, Water, Air, Soil Pollut. 211, 379-393, 2010.

Xu, P., Liao, Y. J., Lin, Y. H., Zhao, C. X., Yan, C. H., Cao, M. N., Wang, G. S., and Luan, S. J.: High-resolution inventory of ammonia emissions from agricultural fertilizer in China from 1978 to 2008, Atmos. Chem. Phys., 16, 1207-1218, https://doi.org/10.5194/acp-16-1207-2016, 2016.

Xu, W., Wang, F., Li, J., Tian, L., Jiang, X., Yang, J., and Chen, B.: Historical variation in black carbon deposition and sources to Northern China sediments, Chemosphere, 172, 242-248, 2017.

Yang, L., Zhou, X., Wang, Z., Zhou, Y., Cheng, S., Xu, P., Gao, X., Nie, W., Wang, X., and Wang, W.: Airborne fine particulate pollution in Jinan, China: Concentrations, chemical compositions and influence on visibility impairment, Atmos. Environ., 55, 506-514, 2012.

Ye, X., Ma, Z., Hu, D., Yang, X., and Chen, J.: Size-resolved hygroscopicity of submicrometer urban aerosols in Shanghai during wintertime, Atmos. Res., 99, 353-364, 2011.

Yin, J., Wang, D., and Zhai, G.: Long-term in situ measurements of the cloud-precipitation microphysical properties over East Asia, Atmos. Res., 102, 206-217, 2011.

Zapletal, M., Kuňák, D., and Chroust, P.: Chemical characterization of rain and fog water in the Cervenohorske Sedlo (Hruby Jesenik Mountains, Czech Republic), Water Air Soil Pollut., 186, 85-96, 2007.

Zimmermann, F., Lux, H., Maenhaut, W., Matschullat, J., Plessow, K., Reuter, F., and Wienhaus, O.: A review of air pollution and atmospheric deposition dynamics in southern Saxony, Germany, Central Europe, Atmos. Environ., 37, 671-691, 2003.

Zipori, A., Rosenfeld, D., Tirosh, O., Teutsch, N., and Erel, Y.: Effects of aerosol sources and chemical compositions on cloud drop sizes and glaciation temperatures, J. Geophys. Res.-Atmos., 120, 9653-9669, 2015. 